\title{
ISOCHILOSTACHYA MYTNIK \& SZLACH., GEN. NOV., A NEW GENUS OF POLYSTACHYINAE SCHLTR. (ORCHIDACEAE)
}

\author{
JOANNA MYTNIK-EJSMONT*, DARIUSZ L. SZLACHETKO \\ Department of Plant Taxonomy and Nature Conservation, Gdansk University \\ Al. Legionów 9, 80-441 Gdańsk, Poland \\ * e-mail: dokjom@univ.gda.pl
}

(Received: March 25, 2010. Accepted: May 11, 2010)

\begin{abstract}
A new genus of Orchidaceae (Polystachyinae), Isochilostachya, is described. It is morphologically similar to Polystachya Hook. but is distinct by the narrower, grass-like leaves arranged in the upper part of the stem, long and acuminate floral bracts and sepals, and long clavate or capitate hairs densely arranged on the lip. A comprehensive description of the new genus is provided. A list of examined specimens and information about distribution, habitat, and altitude for each species are presented. A position of the members of the new genus in the cladogram recently obtained from molecular analyses of Polystachyinae is briefly discussed. A taxonomic key to Polystachyinae is included. Eleven new combinations on species level are validated. Eight lectotypes are designated. Most of the species of Isochilostachya are endemic to particular mountains of the Eastern Arc (Eastern Afromontane hotspot) in north-east Tanzania therefore a brief discussion about their restricted distribution is provided.
\end{abstract}

KEY WORDS: Polystachya sect. Isochiloides, taxonomy, endemism, Eastern Afromontane hotspot, Africa.

\section{INTRODUCTION}

Polystachya Hook. section Isochiloides was described by Summerhayes in 1948. However, nine years earlier (1939) the author suggested that Polystachya isochiloides Summerh., P. shega Kraenzl., and P. goetzeana Kraenzl. should form a new section and placed them in Polystachya section Affines Kraenzl. provisionally. After some years of detailed studies Summerhayes decided to place those three taxa in the new section and included there three newly described species, $P$. caudata Summerh., P. rugosilabia Summerh., and $P$. vaginata Summerh. Thirty years later Cribb (1978) added to Isochiloides next three newly discovered species, P. suavolens P.J. Cribb, P. serpentina P.J. Cribb, and P. lukwangulensis P.J. Cribb., and presented a synopsis to the section. The author transferred to the section P. xerophila Kraenzl. which has since been classified in Polystachya sect. Dendrobianthe Schltr. by Kraenzlin (1926). Although Cribb (1978) did not include P. minima Rendle to the section (classified by Kraenzlin in the ill-defined section Grandiflorae Kraenzl.), but the species is evidently another member of the group.

The representatives of the section are epiphytic (rarely lithophytic or terrestrial) plants of upper montane, montane, and submontane evergreen forest or forest edges. They are characterized by the pseudobulbous stems thickened basally and leafy above, narrow and grass-like leaves with long sheathing petioles below the articulation, pubescent inflorescence (including flowers), long and narrow floral bracts, three-lobed lip densely covered by clavate or capitate hairs, acute middle lip lobe with undulate margins, and relatively long gynostemium.

Considering the results of both molecular (Russell et al. 2010; Mytnik-Ejsmont, in prep.) and morphological studies we propose to classify the species of the section in the taxon of a generic rank.

\section{MATERIALS AND METHODS}

The present study was based on an examination of 94 herbarium specimens from 7 herbaria (AMES, B, BM, BR, $\mathrm{K}$, $\mathrm{P}$, and $\mathrm{W}-\mathrm{R}$ ), The acronyms of herbaria are adopted from Index Herbariorum (Thiers, continuously updated). Astandard procedure of laboring the herbarium material to facilitate stereomicroscopic observation was applied. The vegetative and generative characters of individual plants were analyzed, the flowers were taken from the middle part of the inflorescence and particular parts of the flower were boiled, dissected, measured and drawn under a stereomicroscope. The results were then analyzed and compared with the type material, diagnoses and original illustrations. The database of the drawings and photographs of all studied specimens is available in the first author's 
archives. For all species the type material was examined. The abbreviations of the authors' names follow by Brummitt and Powell (1992), the abbreviations of titles follow those in BPH (Lawrence et al. 1968), BPH/S (Bridson and Smith 1991), TL2 (Stafleu and Cowan 1976) and TL2/S (Stafleu and Mennega 1992).

The present work is a part of a larger project on the taxonomy of the subtribe Polystachyinae Schltr. (Mytnik-Ejsmont 2007; Mytnik-Ejsmont and Szlachetko 2007a, b; Mytnik-Ejsmont 2008, Mytnik-Ejsmont and Szlachetko 2008a, b; Baranow and Mytnik-Ejsmont 2009) and detailed descriptions and drawings of the species as well as a comprehensive list of examined specimens will be provided in the monograph of the subtribe (Mytnik-Ejsmont, in prep.).

\section{TAXONOMIC TREATMENT}

\section{Isochilostachya Mytnik \& Szlach., gen. nov.}

Plantae epiphyticae vel saxicole. Rhizoma breve repens vel paulo evolutum. Caules contigui, saepius erecti, basi in pseudobulbos saepius parvos incrassati, superne graciles et 2-5-phylli. Folia saepius erecta, linearia vel anguste ligulata. Inflorescentiae simpliciter racemose vel e racemis brevibus paucis compositae, pluri- ad multiflorae; bracteae parvae vel mediocres, rarius magnae. Flores satis magni, textura teneri, glabri vel pubescentes, labello saepissime pilis clavatis vel capitatis induto.

GENERITYPE: Isochilostachya isochiloides (Summerh.) Mytnik \& Szlach. (=Polystachya isochiloides Summerh.).

Replaced synonym: Polystachya Hook. sect. Isochiloides Summerh., Kew Bull. 2: 128. 1948.

Etymology: A combination of two words - Summerhayes's name of the section Isochiloides, which comprises the species classified to the newly proposed genus, and Polystachya.

Epiphytic or lithophytic plants up to $50 \mathrm{~cm}$ high, with a short rhizome. Roots up to $4 \mathrm{~mm}$ in diameter, often thick. Stems pseudobulbous basally, slender, terete, and leafy above, clustered, sometimes pendulous, often erect, 2-5-leaved. Pseudobulbs $0.5-2 \mathrm{~cm}$ long, $0.4-10 \mathrm{~mm}$ in diameter at base, of several nodes, ovoid to narrowly conical or conical-ovoid, sometimes obscure, covered by scarious leaf basis. Leaves $5-30 \mathrm{~cm}$ long (including petioles), 0.2-0.8 cm wide, erect or suberect, linear to narrowly-ligulate, obtuse, bilobed, with long sheathing petioles below the articulation with the leaf lamina. Inflorescence 5-30(48) cm long, terminal, erect, simple, racemose or shortly and sparsely branched, one- to many-flowered, shorter or longer than the leaves. Peduncle 3-23 cm long, terete, pubescent, covered with acute, scarious, imbricating sheaths. Rachis terete, pubescent, completely covered by tubular, scarious, acute sheaths. Floral bracts 1-11(15) $\mathrm{mm}$ long, up to $6 \mathrm{~mm}$ wide, lanceolate to transversely ovate or even suborbicular, acuminate, glabrous or rarely sparsely pubescent, usually long and narrow. Flowers small to medium-sized, of delicate texture, scented, glabrous or pubescent, scented, sepals white, cream, yellow to greenish-yellow, sometimes edged with crimson or red-brown central nerve, petals yellow, lip sometimes tinged with purple, callus crimson or green.
Pedicel and ovary 5-10 mm long, often densely pubescent, almost villous. Dorsal sepal 6.5-11.5 mm long, 2-4.5 mm wide, lanceolate to ovate-lanceolate, acute to subacute. Lateral sepals 8-13.5 mm long, 2.5-9 mm wide, lanceolate to obliquely and narrowly triangular-lanceolate, subacute. Mentum 2.5-7.5 mm high, subconical, rounded. Petals 4$-10.5 \mathrm{~mm}$ long, 1.2-3.2 $\mathrm{mm}$ wide, oblanceolate to subspathulate, acute, acuminate or truncate and apiculate. Lip 6.1-12 mm long, 3-7(11) mm wide, shortly clawed, recurved, distinctly to obscurely 3 -lobed in the middle, rarely with an isthmus between the lateral and middle lobes, sometimes minutely pubescent in basal half only but mostly densely covered by clavate or capitate to subcapitate hairs; the lateral lobes 1-1.5 mm long, porrect, narrowly oblong, elliptic to oblong-elliptic or transversely triangular to triangular-ovate, clavately-pilose; the middle lobe 2.5 -5 (7) $\mathrm{mm}$ long, 1.9-4.5(8.5) mm wide, ovate, ovate-lanceolate, obtriangular to transversely-obtriangular, sometimes obcordate-subquadrate or semi-elliptic, rarely soborbicular with crenulate ridges, acute, apiculate or obtuse to rotund, margins often undulate, clavately-pilose; callus, if present, obscure fleshy keel to one-third of the length of the lip. Column 2-4 mm high, stout, semiterete; stigma transversely oblong, anther-cap semipherical, stigma quadrate to suborbicular, rostellum truncate.

The genus comprises 11 species thus eleven new combinations are made herein (in alphabetical order).

Isochilostachya caudata (Summerh.) Mytnik \& Szlach., comb. nov.

Basionym: Polystachya caudata Summerh., Kew Bull. 2: 128. 1948. TYPE (designated here): Tanzania, W. Usambara Mts., Bungu, Moreau 166 (lectotype: K!).

DISTRIBUTION: Tanzania.

HABITAT: In high forest or on isolated trees in plantations. ALTITUDE: $200-1300 \mathrm{~m}$.

RePresentative SPECIMEnS: TANZania: Lushoto Distr.: W. Usambara Mts., Bungu, Moreau 166 (K!); East Usambara Mts., Gombora, 15 miles N. of Amani, Dec 1941, Moreau 782 (K); East Usambara Mts., Monga Mt., near Amani, Nov 1916, Zimmerman s.n. (K).

NOMENCLATURAL NOTE: The lectotype is designated because Summerhayes (1948) did not specify the herbarium where the specimen he chose for the type is deposited.

Isochilostachya goetzeana (Kraenzl.) Mytnik \& Szlach., comb. nov.

Basionym: Polystachya goetzeana Kraenzl., Bot. Jahrb. Syst. 30: 287. 1901. TYPE (designated here): Tanzania, Livingstone Mts., on plateau, Goetze 1279 ( $\mathrm{B} \dagger$, lectotype: K!). DISTRIBUTION: Southern Tanzania, northern Malawi.

HABITAT: An epiphyte of montane and submontane evergreen forest, embedded in moss on branches of trees.

ALTITUDE: $1850-2500 \mathrm{~m}$.

REPRESENTATIVE SPECIMENS: TANZANIA: Dodoma Distr.: Udzungwa Mt. NP, alt. 2040 m., 3 Oct 2000, Luke, Bytebier, Butynski, Ehart, Perkins \& Kimaro 6858 (BR!); Udzungwa Mt NP, Luhomero Mt., alt. 2100 m., Luke, Bytebier, Butynski, Ehart, Perkins \& Kimaro 6868 (EA, $\mathrm{K}$ !); Udzungwa, Luhomero Massif, $7^{\circ} 47^{\prime} \mathrm{S}$, 36 $37^{\circ} \mathrm{E}$, alt. 2450 m., 15 Aug 1985, Rodgers \& Hall 4461 (K!). Iringa Distr.: Kibao, Sep 1914, Leedal 2706 (K); Makete, Kitulo Plateau, alt. 2490 m., 26 May 1987, Iversen, Persson, Pet- 
tersson \& Pocs 87677 (K!); Mufindi, Kigogo Riv., 26 Oct 1977, Leedal 4651 (K!). Mbeya Distr.: Ipinda Forest Station, Jun 1944, Moreau 426 (K!); Ipinda Forest Station, mile 14 on Mbeya-Ghunya Rd, alt. 7900 ft., Moreau 826 (K!); Rungwe, Kiejo Mt. alt. 7100 ft., Leedal 2063 (K!); Undali \& Umalila, Leedal 273a (BR!, K!). Morogoro Distr.: Livingstone Mts., on plateau, Goetze 1279 (K!). Njombe Distr.: Tandala, edge of Mboyo Plateau, Leedal 272 (K!); Njombe, Madope, alt. 2200 m., 28 Sep 1989, Spurrier 94 (K!); Spurrier 85 (K!). Songea Distr.: Matengo Hills, Lupembe Hill, May 1956, Milne-Redhead \& Taylor 10476 (K!).

MALAWI: Nyika National Park, remnant forest patch by road to Kasaramba, alt. 2300 m., 28 Apr 1987, I.F. \& E.A.S. la Croix 1036 (K!); 8 Sep 1986, I.F. \& E.A.S. la Croix 850 (K!); N region, Nyika Plateau, montane forest on the road to Kasaramba, alt. 2300 m., Dowsett-Lamaire $770(\mathrm{~K} !)$

NOMENCLATURAL NOTE: The lectotype is designated because Kraenzlin (1901) did not specify the herbarium where the specimen he chose for the type is deposited.

Isochilostachya isochiloides (Summerh.) Mytnik \& Szlach., comb. nov.

Basionym: Polystachya isochiloides Summerh., Bull. Misc. Inform. Kew 1939: 498. 1939. TYPE (designated here): Tanzania, Handeni District, Mgera, Nyogi Mt., Brutt 4870 (lectotype: K!, isolectotypes: AMES!, B!, BR!, P!).

DISTRIBUTION: Tanzania.

HABITAT: An epiphyte in forest margins, on Acacia in Berlinia-Brachystegia woodland.

Altitude: $600-2400 \mathrm{~m}$.

REPRESENTATIVE SPECIMENS: TANZANIA: Handeni: Nyogi Mt, near Kwediboma, alt. 1220 m., 16 Sep 1933, Burtt 4870 (AMES!, B!, BR!, K!, P!); Handeni Hill, alt. 600 m., 25 Feb 1948, Bally 6379 (K!); Mafisa village, 22 Aug 1993, Kisena 1300 (K!); Lushoto: Gomboro, E Usambara plateau, 12 miles of Amani, alt. $3000 \mathrm{ft}$. Moreau 120 (K!); Amani, alt. 3500 ft., Moreau 375 (K!); W. Usambara Mts., Mkusi, Feb 1942, Doughty in Moreau 120A (K!); Mkusi, near Lushoto, west Usambara Mts., alt. 4500 ft., 27 Feb 1942, Greenway in Moreau 120A (K!); Shekalage, Mazumbai F.R., W Usambaras, alt. 5000 ft., 8 Jan 1976, Cribb \& Grey-Wilson 10071 (K!). Morogoro: Mindu Mt., Sep 1943, Harris in Moreau 688 (K!); Mazumbai F.R., Apr 1975, Tanner 25 (K!); Mt. Kwamba, Ukagurus, alt. 5100 ft., 2 Feb 1976, Tanner 10528 (K!). Kilosa: Malundwe Hill, Mikumi NP, alt. 1140 m. (25 Oct 1983), Lovett 192 (K!). Dodoma: between Dodoma and Babati, alt. 1750 m., Aug 1990, Spurrier 117 (K!); Abercorn, Michelmore in Moreau 237 (K!); Arufield Mt. (?), Kiboriani Range, alt. 5000 ft., Hornby 541 (K!). Tanga: Kiberashi, alt. 5000 ft., Hornby 2027 (K!). Kilimanjaro: Mkomazi Game Reserve, Kisima Hill, 406'S, 3805'E, alt. 1200 m., 9 Jul 1996, Abdallah, Mboya \& Vollesen 96/132 (K!, P!). Arusha: Kingarana Forest reserve, Loliondo, alt. 2400 m., 23 Mar 1995, Congdon 425 (K!). Iringa: Uzungwa Mts., Edekwa village, Nyumbenito Mt., West Kilombero F.R., alt. 6500-7500 ft., Dec 1981, Rodgers-Hall 1949 (K!).

NOMENCLATURAL NOTE: The lectotype is designated because Summerhayes (1939) did not specify the herbarium where the specimen he chose for the type is deposited.
Isochilostachya lukwangulensis (P.J.Cribb) Mytnik \& Szlach., comb. nov.

Polystachya lukwangulensis P.J.Cribb, Kew Bull. 32: 762. 1978. TYPE: Tanzania, Uluguru Mts., Lukwangule Plateau, Drummond \& Hemsley 1668 (holotype: K!).

DISTRIBUTION: Tanzania, known only from the type.

HABITAT: An epiphyte in upland rain forest.

ALTITUDE: $2200 \mathrm{~m}$.

REPRESENTATIVE SPECIMENS: TANZANiA: Morogoro Distr.: Uluguru Mts., Lukwangule Plateau, alt. 2200 m., Mar 1953, Drummond \& Hemsley 1668 (K!).

Isochilostachya minima (Rendle) Mytnik \& Szlach., comb. nov.

Basionym: Polystachya minima Rendle, J. Bot. 33: 198. 1895. TYPE (designated here): Malawi, Blantyre Distr., Shire Highlands, Soche (Sotchi) Mt., December 1894, Scott Elliot 8519 (lectotype: BM!, isolectotype: K!).

- Polystachya malilensis sensu Morris, Epiphyt. Orch. Malawi: 61. 1970, pro parte.

DistRIBUTION: Malawi (endemic to Shire Highlands only). HABITAT: An epiphytic or rarely lithophytic in Brachystegia woodland, on trunks and main branches of trees, in mist, cloud and drizzle.

Altitude: 800-1400 m.

REPRESENTATIVE SPECIMENS: MALAWI: South: Shire Highlands, Blantyre Distr., Soche (Sotchi) Mt., Dec 1894, Elliot 8519 (BM!, K!); Soche Hill, Blantyre, alt. 3500 ft., Morris 105 (K!); Thyolo Distr., Bvumbwe, alt. 1150 m., 6 Dec 1980, la Croix 66 (K!); Blantyre, alt. 3000 ft., Morris 82 $(\mathrm{K} !)$.

NOMENCLATURAL NOTE: The lectotype is designated because Rendle (1895) did not specify the herbarium where the specimen he chose for the type is deposited.

Isochilostachya rugosilabia (Summerh.) Mytnik \& Szlach., comb. nov.

Basionym: Polystachya rugosilabia Summerh. Kew Bull. 2: 129. 1948. TYPE (designated here): Tanzania, Nguru Mts., Moreau 343 (lectotype: K!, isolectotype: EA). DisTRIBUTION: Tanzania (Nguru Mts.).

HABITAT: An epiphyte in deep shade.

ALTITUDE: $900 \mathrm{~m}$.

Representative specimens: TAnZania. Morogoro: Nguru Mts., Aug 1942, Moreau 343 (K!, EA).

NOMENCLATURAL NOTE: The lectotype is designated because Summerhayes (1948) did not specify the herbarium where the specimen he chose for the type is deposited.

Isochilostachya serpentina (P.J.Cribb) Mytnik \& Szlach., comb. nov.

Basionym: Polystachya serpentina P.J.Cribb, Kew Bull. 32: 760. 1978. TYPE: Tanzania, W. Usambara Mts., Bungu, Moreau 781 (holotype: K!).

DISTRIBUTION: Tanzania.

HABITAT: An epiphyte on forest trees.

ALTITUDE: $1200 \mathrm{~m}$.

RePresentative SPECIMEns: TAnZania: Lushoto Distr.: W. Usambara Mts., Bungu, Moreau 781 (K!); W. Usambara Mts., near Mazumbai, Mgwashi, Sep 1975, Tanner 165 (K!, BR!). 
Isochilostachya shega (Kraenzl.) Mytnik \& Szlach., comb. nov.

Basionym: Polystachya shega Kraenzl., Pflanzenw. OstAfrikas, C: 155. 1895. TYPE (designated here): Tanzania, W. Usambara Mts., Mlalo, Holst 2431 (B†, lectotype: K!, isolectotype: W-R!).

DisTRIBUTION: Tanzania, Kenya.

HABITAT: An epiphytic or terrestrial plant, on isolated trees in upland forest or secondary associations.

ALTITUDE: $1500-2300 \mathrm{~m}$.

RePRESEnTATIVE SPECIMENS: TANZANia: Lushoto Distr: Mkuzi, W. Usambaras, alt. 1600 m., 7 Apr 1953, Drummond \& Hemsley 2041 (B!, BR!, K!); W. Usambara Mts., Mlalo, Holst 243 (K!, W-R!); W. Usambara Mts., Mkusi near Lushoto, alt. 1530 m., 9 Mar 1942, Moreau in Doughty 154 (B!, BR!, K!);

KENYA: Coast Prov.: southern end of Chyulu Hills, near Rangers post, 250'S, 37057'E, alt. 1500 m., 7 Aug 1977, Gilbert \& Wiens 4825 (K!). Nairobi Prov.: near Nairobi, 31 Aug 1951, Copley 40 (K!).

NOMENCLATURAL NOTE: The lectotype is designated because Kraenzlin (1895) did not specify the herbarium where the specimen he chose for the type is deposited.

Isochilostachya suaveolens (P.J.Cribb) Mytnik \& Szlach., comb. nov.

Basionym: Polystachya suaveolens P.J.Cribb, Kew Bull. 32: 757. 1978. TYPE: Tanzania, Ulanga Distr., Muhulu, Culwick in Moreau 849 (holotype: K!).

DISTRIBUTION: Tanzania, Malawi.

HABITAT: An epiphyte in montane and submontane evergreen forest; on Syzygium cordatum, on remnant trees.

AltitudE: $1200-2500 \mathrm{~m}$.

RePRESEnTATIVE SPECIMENS: TANZANiA: Ulanga Distr.: Muhulu, Culwick in Moreau 849 (K!); Iringa Distr.: Mufindi, Kigogo R., Leedal 5759 (K!).

MALAWI: Northern Region: Vipya, alt. 1700 m., la Croix 183 (K!); South Viphya, Lwanjati Hills (E of Katete), alt. 1750 m., 14 May 1983, Dowsett-Lemaire 731 (K!). Southern Region: Zomba Plateau, Gassner 9 (K!); 19 (K!); Zomba, alt. 2000 m., la Croix 342 (K!).

Isochilostachya vaginata (Summerh.) Mytnik \& Szlach., comb. nov.

Basionym: Polystachya vaginata Summerh., Kew Bull. 2: 130. 1948. TYPE (designated here): Tanzania, Mbulu Distr., S. side of Ufiome Mt., Moreau 314 (lectotype: K!, isolectotypes: BR!, EA).

- P. isochiloides sensu UKWF: 768. 1974, non Summerh.

- P. shega sensu UKWF: 768, fig. 1974, non Kraenzl.

Distribution: Kenya, Tanzania, Zambia, Malawi, Zimbabwe.

HABITAT: An epiphytic plant on Brachystegia and other trees in deciduous woodland with high rainfall, in montane and submontane forest and rarely in riverine forest, occasionally on rocks.

ALTITUDE: $1000-2260 \mathrm{~m}$.

RePRESENTATIVE SPECIMENS: Kenya: Masai Distr.: Mbagathi, Ngong, Mua Hills, Piers 9 (30 Aug 1950), (K!); 18 (K!); Machakos Distr.: Machakos, alt. 4500 ft., van Someren in Moreau 449 (28 Dec 1942), (K!). Rift Valley: Maparasha Hills, $12 \mathrm{~km}$ ESE of Bisel, alt. 1800-2100 m, 20 Sep 1981, Gilbert 6364 (EA, K!).
TanZaniA: Iringa: Ngozi Mt., Hellquist 30 (K!); Mbulu: S. side of Ufiome Mt., Moreau 314 (BR!, EA, K!); Babati: Bereku F.R., alt. 1630 m., 26 May 1988, Ruffo \& Sigara 3139 B (K!); Njombe: Njombe, Lusitu Ridge, alt. 2260 m., Spurrier 95 (29 Sep 1989), (K!); Ufipa: near Kate Mission, north Ufipa $7^{\circ} 52^{\prime} \mathrm{S}, 31^{\circ} 10^{\prime} \mathrm{E}$, Bell in Moreau $647(\mathrm{~K}$ !); lake Kwela near Mpui, alt. 1350 m., 3 Aug 1960, Richards 12929 (K!).

ZAMBIA: North: Mbala Distr., Kawimbe Rocks, 26 December 1967, Williamson \& Simon 2007 (SRGH).

MalaWI: Central: Chenga Hill, alt. 1600 m., 9 Sep 1946, Brass 17610 (BR!, K!); Cholo Mt. alt. 1300 m., Brass 17793 (K!). South: Zomba Plateau, near Kuchawe Inn, alt. 1500 m., July 1965, Morris 162 (K!).

ZIMBABWE: S. Rhodesia: Vumba, Norseland, alt. $1500 \mathrm{~m}$., 5 Sep 1949, Wild 2977 (K!, SRGH); Vumba, alt. 1500 m. James 24934 (K!); Umtali, Chipondromme Mt., alt. 6500 ft., 15 Jul 1956, Chase 6155 (K!); Umtali, Ball 372 (K!); sine loc.: Bain 1 (K!).

NOMENCLATURAL NOTE: The lectotype is designated because Summerhayes (1948) did not specify the herbarium where the specimen he chose for the type is deposited.

Isochilostachya xerophila (Kraenzl.) Mytnik \& Szlach., comb. nov.

Basionym: Polystachya xerophila Kraenzl., Bot. Jahrb. Syst. 34: 60. 1904. TYPE (designated here): Tanzania, Usambara Mts., Engler 1067a (B†, lectotype: HBG!, K!drawing of the type).

DISTRIBUTION: Tanzania.

HABITAT: An epiphyte on mossy branches in montane forest. ALTITUDE: 1550-1650 m.

REPRESENTATIVE SPECIMENS: TANZANiA: Lushoto Distr.: W. Usambara Mts., Mazumbai. Feb 1976, Cribb \& GreyWilson 10836 (K!); Engler 1067a (HBG!, K!); Bumbuli, Aug 1941, Greenway in Moreau 62 (K!).

NOMENCLATURAL NOTE: The lectotype is designated because Kraenzlin (1904) did not specify the herbarium where the specimen he chose for the type is deposited.

\section{DISCUSSION AND RESULTS}

Morphologically the species of Isochilostachya form a distinct group within Polystachyinae and are easily distinguishable from other genera of the subtribe.

\section{Taxonomic key for determination of the genera of Polystachyinae Schltr.:}

1. Inflorescence lateral.....................Hederorkis Thouars

$1 *$. Inflorescence terminal ...............................................2

2. Free part of the column $8 \mathrm{~mm}$ long, no column foot, lip entire and widest at the apex ......Imerinaea Schltr.

$2^{*}$. Free part of the column up to $6.5 \mathrm{~mm}$ long, usually with a column foot, lip mostly three-lobed .................3

3. Leaves absent at the anthesis....................................4

$3^{*}$. Leaves present at the anthesis ..................................6

4. Lip furnished with a prominent cushion-like crest in the middle, deflexed just above the base, elevated keel present at the base of the lip, lip variously lobed Epiphorella Mytnik \& Szlach.

$4^{*}$. Lip with a single callus, if any, not pulvinate, lip entire. 
5. Plants tiny, up to $2.5 \mathrm{~cm}$ high, column foot very obscure, no mentum .....Geerinckia Mytnik \& Szlach.

$5^{*}$. Plants more than $10 \mathrm{~cm}$ high, mentum and column foot prominent, 3-6 mm high ..........Dendrobianthe Mytnik

6. Robust plants $50-120 \mathrm{~cm}$ high with pseudobulbs, sepals 16-20 mm long, mentum 5-6.5 mm long.

......Neoburttia Mytnik, Szlach. \& Baranow (in press)

$6^{*}$. Not as above

7. Inflorescence pendent or apically drooped, lip of lowermost position.

$7^{*}$. Inflorescence erect to semi-erect, lip of uppermost position

8. Pseudobulbs large, spherical, succulent, flattened on the substratum, inflorescence pendent

Chelystachya Mytnik \& Szlach. (in press)

$8^{*}$. Pseudobulbs absent, stem reed-like, inflorescence erect with a rachis apically drooped.

Neobenthamia Rolfe

9. Spur very long and narrow, three times longer than the dorsal sepal ..Disperanthoceros Mytnik \& Szlach.

9*. Spur (mentum) up to two times longer than the dorsal sepal.

10. Whole plant pendent or creeping, leaves fleshy, imbricate, and bilaterally flattened.

Szlachetkoella Mytnik

$10 *$ Plant neither pendent nor creeping, leaves not imbricate .....

11. Lip furnished with a prominent cushion-like crest in the middle, lip deflexed just above the base, elevated keel present at the lip base

Epiphorella

$11^{*}$. Lip with a single callus, if any, not pulvinate, lip rarely slightly deflexed at the base ...........................12

12. Lip with a long claw, at least third of the lip length, lip divided into 3 parts with the mesochile variously lobed, mentum elongate, saccate, swollen at the apex.

Unguiculabia

12*. Lip shortly clawed or sessile, lip usually 3-lobed, then divided into the lateral and middle lobes, mentum conical-saccate, obtuse.....

13. Leaves elliptic, ovate or obovate, lip often furnished with pseudopollen, sepals up to $8 \mathrm{~mm}$ long, obtuse, column short and massive, 1-2.5 mm high

Polystachya

13*. Leaves narrow, grass-like, lip without pseudopollen, covered with numerous clavate or capitate prominent, long hairs, sepals more than $8.5 \mathrm{~mm}$ long, acuminate, column slender, 2-4 mm high ............Isochilostachya
Isochilostachya is closely related to Polystachya but they differ in the leaves, floral bracts, and sepals form and length, the lip pubescence, and the gynostemium length. The leaves of the former genus are linear, ligulate or narrowly-ligulate and grass-like with prominent, long sheathing petioles below the articulation with the leaf lamina and most often arranged in the upper part of the stem, whereas those of Polystachya are predominantly elliptic, oblong, lanceolate or oblanceolate and arranged in the basal half or along the stem, rarely in its upper part. Members of Isochilostachya differ from Polystachya in floral bracts and sepals length, which are generally much longer and acuminate in the former genus. A very characteristic and easily distinguishable from other genera of Polystachyinae is lip pubescence present in most of the species of Isochilostachya. The lip hairs are relatively long, clavate or clublike, capitate to subcapitate, one- to three-celled and are not pseudopollen, which is so characteristic to many species of Polystachya. The gynostemium structure is similar in both genera, however, free part of the column is longer and slightly more slender in Isochilostachya (2.5-4 $\mathrm{mm}$ high) than in Polystachya, in which the gynostemium (without the column foot) is short, stout, and massif, averaging 1$-2.5 \mathrm{~mm}$ high in most species. The main difference between both genera are presented below (Table 1).

Summerhayes (1948) noted that plants representing the section Isochiloides are intermediate in morphological characters between the representatives of the sections Affines and Dendrobianthe Schltr. They resemble the latter in slender stems thickened basally into pseudobulbs and the narrow, grass-like leaves and the former taxon in the three-lobed lip with an acute middle lobe. Moreover, the lip hairs are somewhat similar to those of the section Affines and the genus Dendrobianthe, but usually are much shorter. The results of recent molecular studies (Russell et al. 2010) confirm the uniqueness of those three groups mentioned by Summerhayes (1948). The taxa (along with $P$. ottoniana Rchb.f.) form four earliest lineages of Polystachyinae (represented by $P$. affinis Lindl., $P$. ottoniana, $P$. longiscapa Summerh., and Neobenthamia-Dendrobianthe group) and then are followed by clades represented by species of Polystachya s.str. The authors of molecular analyses state that Polystachya is monophyletic if Neobenthamia gracilis Rolfe is transferred to Polystachya. However, in our opinion, Neobenthamia should be included within Polystachya. The latter genus differs from Polystachya in numerous features (terrestrial form of life, rachis

TABLE 1. The differences between Isochilostachya Mytnik \& Szlach. and Polystachya Hook.

\begin{tabular}{lll}
\hline & Isochilostachya & Polystachya \\
\hline Stems & Slender, thickened at the base & $\begin{array}{c}\text { Of various type, from cane-like and not thickened, to thickened basally } \\
\text { or at the whole length }\end{array}$ \\
\hline Leaves & Narrow, grass-like & Elliptic, ovate or obovate, rarely narrow \\
\hline Dopals & Acuminate & Obtuse, rounded with an apiculus, acute or acuminate \\
\hline Lip & More than 8.5 mm & Shorter than 8 mm \\
\hline
\end{tabular}

Free part of column More or less slender and relatively high, up to $4 \mathrm{~mm}$

Short and massive, usually 1-2.5 mm high 
apically drooped, racemose corymbose inflorescence, uppermost lip, no mentum, lack or rudimentary column foot) and incorporating that taxon within Polystachya makes the latter genus polymorphic (more detailed discussion will be presented in the monograph of the subtribe, Mytnik-Ejsmont, in prep.). As Neobenthamia is a distinct genus, the other taxa representing basal "species-poor lineages" are distinct genera and we tend to recognize them as such, these are Chelystachya (Mytnik-Ejsmont et al., in press), Neoburttia (Mytnik-Ejsmont et al., in press), Neobenthamia, Dendrobianthe, and Isochilostachya (P. ottoniana is the only taxon which requires further detailed studies because of inexplicable position in the tree).

According to the results of the molecular analyses (Russell et al. 2010) members of the section Isochiloides (=Isochilostachya) appear to form a monophyletic clade with a good support (100\%) being the last of four earliest lineages of Polystachyinae. In our recognition of the genus, Polystachya s.str. contains "clades I to V" sensu Russell et al. (2010). According to the latter authors the section Isochiloides (=Isochilostachya) is sister to the single large clade of Polystachya s.str.

Isochilostachya is confined to eastern Africa, it ranges from Kenya south to Tanzania and Malawi. However, the vast majority of the species are strict or near endemics occurring in the Eastern Arc in north-east Tanzania (Temu and Andrew 2008). According to White's (1983) phytogeographical classification, the ecoregion forms part of the Afromontane archipelago-like regional center of endemism. The Eastern Arc Mountains are part of the Eastern Afromontane biodiversity hotspot (Mittermeier et al. 2004) and one of the most important regions for conservation in the world (Stattersfield et al. 1998; Myers et al. 2000; Olson and Dinerstein 2002). The mountains support ca. 3300 sq. $\mathrm{km}$. of closed-canopy tropical rainforest and according to Burgess et al. (2007) this may be less than $30 \%$ of the original forest cover. This region is significant in having their endemic species concentrated in exceptionally small area, with 1500 endemic plants on 2000 square kilometers (Myers 2000). Such extreme accumulation of endemics in the remaining habitats of Eastern Arc indicates the degree to which the plants in this region are threatened. The mountains generally contain a small area of forest, isolated from other similar forests. Although the evidence of the long period of relative climatic stability of the Eastern Arc Mountains is still lacking (Fjeldså et al. 1997; Lovett et al. 2005) the region has been proposed as one of the forest refugia in Africa retaining moist forest through the last glaciation (Diamond and Hamilton 1980; Hamilton 1982) and probably the lineages that became extinct elsewhere in East Africa have been able to survive in the Eastern Arc. Most of species of Isochilostachya is restricted in their distribution to these ancient mountains (mainly Nguru Mt., Usambara Mts., and a few isolated peaks between Usambara and Uluguru Mts.) and it is likely they represent one of the earliest extant lineages of Polystachyinae. According to Munishi et al. (2004) species of restricted distribution are very fragile in an ecosystem and can easily be driven to extinction. The species of Isochilostachya, as endemics and near endemics, should be a subject of very careful conservation action.

\section{ACKNOWLEDGMENTS}

We would like to express our gratitude to Dr. Jeffrey Wood and Dr. David Roberts (K) for their help during our several visits to $\mathrm{K}$ herbarium. This study was supported with the grant from Ministry of Science and Higher Education (N N303 343735).

\section{LITERATURE CITED}

BARANOW P., MYTNIK-EJSMONT J. 2009. Two new species of Polystachya (Vandoideae, Orchidaceae) from Africa. Plant Syst. Evol. 281: 11-16.

BRIDSON G.D.R., SMITH E.R. 1991. B-P-H/S: Botanico-Periodicum-Huntianum-Supplementum. Hunt Institute for Botanical Documentation, Carnegie Mellon University, Pittsburgh, Pennsylvania.

BRUMMITT R.K., POWELL C.E. 1992. Authors of Plant Names: A list of authors of scientific names of plants, with recommended standard forms of their names, including abbreviations. Royal Botanic Gardens, Kew, England.

BURGESS N.D., BUTYNSKI T.M., CORDEIRO N.J., DOGGART N.H., FJELDSÅ J., HOWELLI K.M., KILAHAMA F.B., LOADER S.P., LOVETT J.C., MBILINYI B., MENEGON M., MOYER D.C., NASHANDA E., PERKIN A., ROVERO F., STANLEY W.T., STUART S.N. 2007. The biological importance of the Eastern Arc Mountains of Tanzania and Kenya, Biol. Conserv. 134: 209-231.

CRIBB P.J. 1978. Studies in the genus Polystachya (Orchidaceae) in Africa. Kew Bull. 32: 743-766.

DIAMOND A.W, HAMILTON A.C. 1980. The distribution of forest passerine birds and Quaternary climatic change in tropical Africa. J. Zool. 191: 379-402.

FJELDSÅ J., EHRLICH D., LAMBIN E., PRINS E. 1997. Are biodiversity 'hotspots' correlated with current ecoclimatic stability? A pilot study using the NOAA-AVHRR remote sensing data. Biodiversity and Conservation 6: 401-422.

HAMILTON A.C. 1982. Environmental history of East Africa: a study of the Quaternary. London: Academic Press.

KRAENZLIN F. 1895. Orchidaceae. In: A. Engler (ed.), Die Pflanzenwelt Ost-Afrikas und der Nachbargebiete: 155. Berlin.

KRAENZLIN F. 1901. Orchidacearum genera et species, Vol. 1. Habenaria. Mayer and Müller. Berlin.

KRAENZLIN F. 1904. Orchidaceae africanae. Botanische Jahrbücher für Systematik, Pflanzengeschichte und Pflanzengeographie 34: 60 .

KRAENZLIN F. 1926. Monographie der Gattung Polystachya Hook. Repert. Spec. Nov. Regni Veg. Beih. 39: 1-136.

LAWRENCE G.H.M., BUCHHEIM A.F.G., DANIELS G.S., DOLEZAL H. 1968. Botanico-Periodicum-Huntianum. Hunt Botanical Library, Pittsburgh.

LOVETT J.C., MARCHANT R., TAPLIN J., KÜPER W. 2005. The oldest rain-forests in Africa: stability or resilience for survival and diversity? In: A. Purvis, J.L. Gittleman, T.M. Brooks (eds), Phylogeny and Conservation: 198-229. Cambridge University Press, Cambridge.

MITTERMEIER R.A., ROBLES GIL P., HOFFMANN M., PILGRIM J., BROOKS T., MITTERMEIER C.G., LAMOREUX J., DA FONSECA G.A.B. 2004. Hotspots Revisited. Mexico: CEMEX.

MUNISHI P.K.T., SHEAR T.H., WENTWORTH T., TEMU R.P.C., MALIONDO S.M. 2004. Sparse distribution pattern of some plant species in two afromontane rain forests of the Eastern Arc Mountains in Tanzania. J. Forest Nat. Conserv. 75: 74-90.

MYERS N., MITTERMEIER R.A., MITTERMEIER C.G., DA FONSECA G.A.B., KENT J. 2000. Biodiversity hotspots for conservation priorities. Nature 403 (6772): 853-858. 
MYTNIK-EJSMONT J. 2007. Materials to the revision of Polystachyinae Schltr. (Orchidaceae). 1.Szlachetkoella Mytnik, gen. nov. Richardiana 7(2): 55-60.

MYTNIK-EJSMONT J., SZLACHETKO D.L. 2007a. Materials to the revision of Polystachyinae Schltr. (Orchidaceae). 2. Geerinckia Mytnik \& Szlach., gen. nov. Richardiana 7(2): 61-63.

MYTNIK-EJSMONT J., SZLACHETKO D.L. 2007b. Materials to the revision of Polystachyinae Schltr. (Orchidaceae). 3. Disperanthoceros Mytnik \& Szlach., gen. nov. Richardiana 7(2): 64-66.

MYTNIK-EJSMONT J. 2008. Materials to the revision of Polystachyinae Schltr. (Orchidaceae). 6. Dendrobianthe (Schltr.) Mytnik \& Szlach., gen. et stat. nov. Richardiana 8(1): 23-27.

MYTNIK-EJSMONT J., SZLACHETKO D.L. 2008a. Materials to the revision of Polystachyinae Schltr. (Orchidaceae). 4. Epiphorella Mytnik \& Szlach., gen. nov. Richardiana 8(1): 12-17.

MYTNIK-EJSMONT J., SZLACHETKO D.L. 2008b. Materials to the revision of Polystachyinae Schltr. (Orchidaceae). 5. Unguiculabia Mytnik \& Szlach., gen. nov. Richardiana 8(1): 18-22.

OLSON D.M., DINERSTEIN E. 2002. The global 200: priority ecoregions for global conservation, Ann. Missouri Bot. Gard. 89: $199-224$.

RENDLE A.B. 1895. The Sumjiee Flora of Bigbury Bay. Journal of Botany 33: 200.

RUSSELL A., SAMUEL R., RUPP B., BARFUSS M.H.J., ŠAFRAN M., BESENDORFER V., CHASE M.W. 2010. Phylogenetics and cytology of a pantropical orchid genus Poly- stachya (Polystachyinae; Vandeae; Orchidaceae); evidence from plastid DNA sequence data. Taxon 59: 389-404.

STAFLEU F.A., COWAN R.S. 1976. Taxonomic Literature: A Selective Guide to Botanical Publications and Collections with Dates, Commentaries and Types. Ed. 2. Regnum Vegetabile, Bohn, Scheltema and Holkema, Utrecht, The Netherlands.

STAFLEU F.A., MENNEGA E.A. 1992. Taxonomic Literature: A Selective Guide to Botanical Publications and Collections with Dates, Commentaries and Types. Supplement. Regnum Vegetabile, Koeltz Scientific Books, Königstein, Germany.

STATTERSFIELD A.J., CROSBY M.J., LONG A.J., WEGE D.C. 1998. Endemic Bird Areas of the World: Priorities for Biodiversity Conservation, Bird Life International, Cambridge, UK.

SUMMERHAYES V.S.S. 1939. African Orchids: XI. Bull. Misc. Inf. Kew 1939(9): 498-499.

SUMMERHAYES V.S.S. 1948. African Orchids: XVII. Kew Bull. 2(2): 128.

TEMU R.P.C., ANDREW S.M. 2008. Endemism of plants in the Uluguru Mountains, Morogoro, Tanzania. Forest Ecol. Manag. 255: $2858-2869$.

THIERS B. (continuously updated). Index Herbariorum: A global directory of public herbaria and associated staff. New York Botanical Garden's Virtual Herbarium. http://sweetgum.nybg. org/ih/

WHITE F. 1983. The vegetation of Africa, a descriptive memoir to accompany the UNESCO/AETFAT/UNSO Vegetation Map of Africa (3 Plates, Northwestern Africa, Northeastern Africa, and Southern Africa, 1:5,000,000). UNESCO, Paris. 


\section{ERRATUM}

Elżbieta Cieślak, Zbigniew Szeląg:

"Genetic diversity of Galium cracoviense, G. oelandicum and G. sudeticum (Rubiaceae) - narrow endemic species of Galium sect. Leptogalium in northeastern Europe".

Unfortunately in the paper published in the previous volume (Vol. 79, No. 4: 269-275, 2010) numerous errors appeared due to Editor's oversight. The editor regrets any confusion this has caused.

The correct version of that paper is available as a PDF file at:

http://www.ib-pan.krakow.pl/ibwyd/ptbactasoc/ptb-actasoc-2010.html 